Animals illustrated

\author{
D.R. Newth
}

Integrated Principles of Zoology,

7th Edn.

By Cleveland P. Hickman Jr, Larry S.

Roberts and Frances M. Hickman.

Times Mirror/Mosby/Blackwell

Scientific: 1984. Pp. 1,065. \$34.95, £38.

General Zoology, 6th Edn.

By Claude A. Villee, Warren F. Walker

$\mathrm{Jr}$ and Robert D. Barnes.

Holt Saunders/Holt, Rinehart \&

Winston: 1984. Pp.992. Hbk £22.95,

\$36.95; $p b k$ f18.95.

EACH of these texts is about thirty years and half-a-dozen editions removed from its first appearance. Each is the work of three authors who acknowledge help in revision from many sources. Each is large and lavishly illustrated, devotes its largest single section to a systematically arranged account of the animal kingdom, but gives over half its total length to sections on behaviour, cell biology, ecology, genetics and physiology. Both sets of authors, in fact, have tried to include in one volume the minimum background of chemical and biological science necessary to make sense of any, or all, forms of animal life. In consequence they have had to be sparing in their descriptions of actual animals. The balance struck in both books is, I think, about right for texts at this level.

It would be surprising if many of the idiosyncracies, personal opinions on matters in dispute, or even the occasional lapses in matters of fact or of taste which endear the single-author book to the reader, could survive the editorial process in a middle-aged text produced for large numbers of undergraduate students. These losses are the price we pay for a gain in reliability and for a reduced danger of major omission. These two books, having set out with similar aims, have adopted broadly similar methods and have succeeded to much the same extent.

However the two are not indistinguishable. Hickman et al. is the more relaxed in tone, the more generously produced and, perhaps, the more willing to comment, from the zoologist's point of view, upon matters of public or lay interest. Thus the book ends with a chapter on animals in the human environment which gives a balanced but forceful treatment of the need to adopt conservation measures worldwide and without delay. Old-fashioned textbooks might mourn the extinction of species, but would hesitate to quote specific legislation and litigation in describing any one case. The story of the attempts to save the snail darter from the effects of building the Tellico dam may well serve to excite more interest in that unfortunate fish than it would ever otherwise have received.

Hickman et al. is the more colourful book in the literal sense, using colour photographs freely and sometimes to pleasing effect. Whether or not this always adds to the value of the illustration is perhaps doubtful. It also evades the modern publisher's unhappy proscription of footnotes by allowing use of the wide margins of the printed page for "marginal notes" in which additional or peripheral matter can be added without stemming the flow of the main story. A similar, but less sightly, trick is used by Villee et al. who place such matter in "boxes" which can take up much of the page. This apart Villee et al. is altogether more reserved in presentation, both visually and in the text. It provides a businesslike account of its material, but must be faulted for a rather cavalier treatment of some important arẹas. Parasitology, the insects of economic importance, indeed the insects as a whole, and regeneration are cases in point. While my own preference would be for the more lively and imaginative approach of Hickman et al., there is not a great deal in it.

D.R. Newth was formerly Regius Professor of Zoology at the University of Glasgow.

\section{Aspects of insects}

\section{M.E.G. Evans}

Insect Biology: A Textbook of

Entomology.

By Howard E. Evans.

Addison-Wesley: 1984. Pp.436. \$32.95,

f14.95.

Insect Physiology, 8th Edn.

By V.B. Wigglesworth.

Chapman \& Hall/Methuen: 1984.

Pp. 191. Hbk 115, \$35; pbk 17.95, \$15.95.

INSECTS are now studied as living animals rather than as stamps in collections, and this changed attitude is reaching student texts. Both of these books deal with insects as living organisms: their forms, functions and lifestyles. The first book is a fairly large general text, which concentrates particularly upon the behaviour, physiology and ecology of insects, whilst the second is a concise introduction to their physiology.

Some years ago, H.E. Evans wrote what was probably the best recent book on insects which was comprehensible to the general public (Life on a Little-known Planet, published by Dutton in 1968), so 1 received his textbook with great interest and anticipation. In fact, this is a multi-author work, as Evans has five colleagues as co-authors, but the style is consistent and a high standard of clarity is maintained throughout.

The 18 chapters are grouped into seven parts dealing respectively with structure and diversity, functions and development, behaviour, plant-insect relationships, relationships with animals, ecology and pest management. There is also an appendix on non-insectan Arthropoda which is followed by a useful glossary. Each of the chapters concludes with a summary followed by "selected readings"; these include the most pertinent references, but might have been longer and more comprehensive. With few lapses, the text is written simply and informatively, and the illustrations are mostly straightforward line diagrams which are neatly boxed to separate them from the text. The traditional entomological preoccupations with morphology, taxonomy and diversity have been condensed into the first section to allow for expansion of the later parts.

Wigglesworth's book is a new edition of a well-established work; indeed, there can be very few authors who have produced a new edition of their book a full halfcentury after the original date of publication. It covers the traditional range of insect physiology by describing the operation of the various organ systems (many of which have been elucidated by Sir Vincent himself over considerably more than the past 50 years). Although similar to earlier editions, much new material has been incorporated, and more subheadings have increased the accessibility of different subjects in the text. The references have been updated and many new figures added, while the narrative is still admirably readable and comprehensible.

Insect Physiology was originally a pioneer in the Methuen Monograph series - little books which were a great boon to earlier generations of student biologists who lacked the huge diversity of modern textbooks. But even if the texts reviewed here are both good in their different ways, do modern students need yet more books, recycled or new? If an established text can be revised adequately, there is good reason to keep it. Wigglesworth's small (but expanding) book probably is most useful in providing an introduction to insect physiology for non-entomological zoologists, or to whet the appetite of entomology students at an early stage of their training. More advanced students will need his Principles of Insect Physiology (Chapman \& Hall, 7th Edn 1972), or an equivalent expanded treatment.

A new entomology text must provide a fresh look at the subject in order to compete, and Evans has had the advantage of being able to take a contemporary viewpoint throughout. Insect Biology would provide an excellent basis for a modern entomology course taught as one of several subjects for a zoology or biology first degree. For a more specialist entomology course, morphological and systematic reinforcement would be necessary, as provided, for instance, by Borror, DeLong and Triplehorn's $A n$ Introduction to the Study of Insects (Holt, Rinehart \& Winston, 5th Edn 1981) or Imms' General Textbook of Entomology (Wiley/Chapman \& Hall, 10th Edn 1977).

M.E. G. Evans is a Senior Lecturer in Zoology at the University of Manchester. 